\title{
Bridging Food Security and Sustainable Agriculture Development through Regional Planning
}

\author{
Melinda Noer \\ * Agriculture Department, Faculty of Agriculture, Universitas Andalas, Padang, Indonesia \\ E-mail: melindanoer@yahoo.com
}

\begin{abstract}
For years, food security and sustainable agriculture development intensively being discussed individually or simultaneously from many point of views and aspects, and both definitely have integrations. However, it is commonly found that they are being implemented separately. This paper is arguing that food security and sustainable agriculture must be brought into spatial and a spatial development approach within the regional planning thought. Regional planning is a kind of communicative planning process which will bridge the objectives of food security to the sustainable agriculture development, either as a public policy or in its implementation. Food as human basic needs and sustainable agriculture as a development concept to fulfil human basic needs, desire regional planning that will communicate both the objectives. So, the deviation between public policy and its implementation can be shortened at the global, regional, or local level. Indonesia and West Sumatra regional context in some cases will be explained to show the objective of this paper.
\end{abstract}

Keywords — food security; agriculture development; sustainable; regional planning

\section{INTRODUCTION}

Food security and sustainable agriculture development have very closed integrations and need multidisciplinary sights to be achieved. Food as basic human needs have to be directed with public policy which is proper and transparent since it will impact on the economy, social and political stabilization of the country. Therefore, food security in the conception of country rights and people self-sufficiency have to be supported by the integration of spatial (land use) and development planning within regional planning, which also necessary in agriculture development. The main objective of the food security is to build food system which suit to potential local resources. In relation to this, [1] revealed that very little information to explain the impact of long-term use of land on food security at the local level, since it is not a priority and important issue in land use planning. Respectively, agriculture development should actually be designed to meet food security in the one hand, and sustainable development in the other hand.

Food security means a condition where household meets their food in terms of its availability, safety, equity and accessibility to some extent which based on local and national oriented. This concept is in relation to food security defined by Food Agriculture Organization-United Nations where the country is secure in food if they can meet their food although it is not produced by the country itself. But, this can't ensure its sustainability because state and people are not autonomy to determine food system that suitable to their local resources.

Food security and agriculture development have been discussed many times in many countries, in individual as well as simultaneous event. However, food insecurity still being faced as crucial problems for many countries, especially in developing countries in the world. It is about $30 \%$ of people in malnourishment around the world. Indonesia, for instance faced food crisis on meat supply and rice production which resulted in unreasonable price that increased until $30 \%$ of its normal price last year [2].

The food crisis in some cases happen because of food security and agriculture development program is seen as fragmented problems. They must be linked with the regional approach to know where, how, how much and when food are produced and available, distributed and secured for people health. This paper discusses about how agriculture development can be planned within the concept of sustainability to attain food security by integrated multidisciplinary within regional planning. Furthermore, it also can be evaluated where the area or potential land for food as well as other resources and budget are feasible. So that we can completely plan about land and input allocation, food distribution, quality and safety, infrastructure, technology in production and processing the harvest, consumer accessibility on food, etc. As the result, sustainability in agriculture development from upstream to 
downstream can be maintained as a food security system and continued to attain its objectives in future.

\section{FoOD SECURITY AND AGRICULTURE DEVELOPMENT}

Based on that thought, food security is now found as a multi-aspects issue and extended to more than food supply and demand. In the 1996 at World Food Summit, countries agreed that food security is about people access to sufficient, safe and nutritious food for their lifetime. Further, in 2002, [3] gave a working definition of food security: "food security exists when all people, at all times, have physical, social and economic access to sufficient, safe and nutritious food which meets their dietary needs and food preferences for an active and healthy life". It means that food security is measured as food at family level whereas individuals within households.

Subsequently, food security depends on the affordability of country's ability on food availability, the capability of people to access food, and food utilization by household. In Indonesia, public policy on food security is designed as human rights on food to attain a human eminence. Indonesian food regulation defined that "food is all safe and healthy things that sourced by agriculture production in kind of food crop, industrial crop, forestry crop, or product of fishery, poultry, whether in wetland or prairie, which processed or not, that is used for meals or drinks for human consumption included additional food, staple food, or others in its preparation, processing or making meals and drinks" [4]. Rice is the staple food of Indonesian in most parts of country. Rice consumption average rate in Indonesia in the period of 2007-2011 was above $100 \mathrm{~kg} / \mathrm{capita} / \mathrm{year}$, which was $0.7 \%$ consumption growth rate. In the same period, West Sumatra Province stated the average consumption rate was about $112.65 \mathrm{~kg} / \mathrm{capita} /$ year, with a decreasing growth consumption rate was about $1.07 \%$ a year. Although consumption and production rate statistically is still quite balanced, but the price is tend to be growing because of market shortage. Meat consumption in Indonesia is considered to be low, that is only $1.64 \mathrm{~kg} /$ capita/year [5], because of its high price.

It means that food price is also a determinant to reach food security at the individual or household level. So that, food security is defined as an achievement food condition from state to individual people, which can be observed by availability of food in quality and quantity, safety, diversity, healthy, nutritious, evenly, affordable and appropriate to religion, principle and social culture to reach the aims of sustainable healthy life, active, and productive [6], [7]. Furthermore, to meet the objectives of food security, we need to develop agriculture as sources of primary product for food. Although food security is more than an availability of products for food, but its availability is a start point to make a decision on distribution, accessibility, and utilization of food. Based on above description, the portrait of food security can be described as Table 1.
TABLE I

FOOD SECURITY DESCRIPTION AND INDICATORS

\begin{tabular}{|c|c|c|c|}
\hline Aspects & Description & Indicators & Results \\
\hline $\begin{array}{l}\text { Food } \\
\text { Availability }\end{array}$ & $\begin{array}{l}\text { Availability } \\
\text { of food from } \\
\text { the State to } \\
\text { individual } \\
\text { household }\end{array}$ & $\begin{array}{l}\text { - Quantitatively } \\
\text { Sufficient } \\
\text { - Qualitatively } \\
\text { Sufficient } \\
\text { - Safety } \\
\text { - Nutritious } \\
\text { - Diversity }\end{array}$ & $\begin{array}{l}\text { - Active and } \\
\text { healthy life } \\
\text { - Local } \\
\text { - Suitability } \\
\text { - Sustainability }\end{array}$ \\
\hline Food Access & $\begin{array}{l}\text { Household or } \\
\text { individual } \\
\text { capability / } \\
\text { ability to } \\
\text { obtain food }\end{array}$ & $\begin{array}{l}\text { - Individual's } \\
\text { capability } \\
\text { - Physical, Social, } \\
\text { Culture and } \\
\text { Economic } \\
\text { approachability } \\
\end{array}$ & \\
\hline $\begin{array}{l}\text { Food } \\
\text { Utilization }\end{array}$ & $\begin{array}{l}\text { Household or } \\
\text { individual } \\
\text { suitability to } \\
\text { proper } \\
\text { consumption }\end{array}$ & $\begin{array}{l}\text { - } \text { Proper } \\
\text { preparation } \\
\text { - Proper storage } \\
\text { - Proper utilization } \\
\text { - Safety } \\
\text { - Healthy }\end{array}$ & \\
\hline
\end{tabular}

\section{SuStAinABLE AgRICUlture DEVELOPMENT AND REGIONAL PLANNING}

Sustainable development' is "development that meets the needs of the present without compromising the needs of future generations to meet their own needs" [8]. Core concept of sustainable is a belief that social, economic and environmental objectives should be complementary and interdependent in the development process. It is being more realized that food security achievement should be started from multidisciplinary approach [9] and sought intensively in both the number of terms and diversification of fields of study [10]. Sustainable development has three principal dimensions: economic growth, social equity and protection of the environment. In relation to this thought, food security in agriculture development context requires the involving of the theories, concepts, and practices of sustainable agriculture development from upstream (inputs) to downstream (processing and marketing) as a whole system. Therefore, food security is in fact not dealing with agriculture sector only, but the non-agriculture sector as well. Food security involves multi-sector thoughts (multidisciplinary) and responsible from upstream to downstream as a system, among others are:

1. Land use planning (spatial planning) to make sure the availability and suitability of land for agriculture cultivation.

2. Production inputs for agriculture such as seeds, organic fertilizer, organic pesticide, machine, etc.

3. Availability of agriculture labourers.

4. Infrastructure requirements for agricultural production such as irrigation services and agro-industry development.

5. Technology in agriculture product processing to increase product diversification and added value.

6. Agriculture product marketing in relation to market price, marketing system and institutions.

7. Financing or banking to increase accessibility for farm and non-farm funding.

8. Formal and informal education such as extension services and community development. 
9. Transportation for input and product distribution.

10. Health sector to maintain safety and good food for healthy consumption.

In one hand, the national and regional government in Indonesia has actually been implementing several programs in order to attain food security within regional based agriculture development by zoning regional functions. Some among others which have been implemented in terms of irrigated zone, agropolitan zone, food security zone, secured food household zone, agro-technopark zone, integrated agriculture zone, etc. Besides, rural agriculture development is also implemented in the form of national programs for people empowerment in the rural area [11]. But, in the other hand, we have also been facing agricultural land conversion to non-agricultural land [12], which is in some cases not based on land use plan and regulation. It will continuously lead to a risk of carrying capacity of region to meet food security objectives.

In fact, productive land conversion happens at an alarming rate. Indonesia had loss of 200,000 hectares of highly productive wetlands annually within $2008-2010$. The rate of about $50 \%$ of the total 7.8 million hectares of wetlands is in alarming to danger. Rates of new wetland development outside Java cannot meet the rate of land conversion while the productivity of non-Java wetlands is still lower. So that, Indonesia will lose its highly productive wetlands within 20 years if no significant land protection is enforced [5].

To foresee that problem, it has stated in national regulation that national, provincial and district or local level consistently determine certain agriculture area for food land protection. This policy is in relation to the aim of food security [13]. The regulation also aims economically at increasing of farmer income, socially to change farmer perception from conventional farmer to professional farmer, and ecologically to conserve the environment. Nevertheless, integration of food security program and agriculture development into regional planning are still less priority and opportunity, since there is the lack of controlling which then lead to the unsustainable condition. Sustainable agriculture must encounter economic, social and ecological challenges which are closely related.

In some conditions, to increase food availability in the country, numerous macro policies and programs such as building buffer stocks and controlling prices have also been implemented. But, in reality, food security programs are effective only if individuals have access to food, and many households do not have income enough to buy food. So, many south Asian countries have introduced income based or employment generating programs along with price control and distributive measures, including direct cash transfers [14]. In some situations, the government sometimes adopts an import policy as a rapid way to meet national demand for agricultural goods, which also happens to Indonesia. Owing to current shortage of red meat, raw chilli, and onions, the central government delivers import licenses to fill the shortage, which will not answer the food security challenges for long term planning to attain sustainable development in future.

\section{FOOD SECURITY AND SUSTAINABLE AGRICULTURE DEVELOPMENT IN REGIONAL PLANNING}

Those considerations above give the reasons why regional planning is essential to bridge food security and agriculture development to attain its sustainability. Regional planning will give a principle guidance to determine food security, from upstream to downstream as a system, which integrate multi sectors in agriculture development and obviously can be used to measure its achievement. Regional planning is understood as an approach and a bridging process to link food security and sustainable agriculture development. Table 2 is to show how food security aspects can be integrated with sustainable agriculture development through regional planning.

TABLE II

INTEGRATION OF FOOD SECURITY AND SUSTAINABLE AGRICULTURE DEVELOPMENT IN REGIONAL PLANNING

\begin{tabular}{|c|c|c|}
\hline Food Security & $\begin{array}{c}\text { Sustainable } \\
\text { Agriculture } \\
\text { Development }\end{array}$ & Regional Planning \\
\hline Availability & $\begin{array}{l}\text { Economically, } \\
\text { Environmentally }\end{array}$ & $\begin{array}{l}\text { - Land use planning: } \\
\text { input and output } \\
\text { location and allocation, } \\
\text { land suitability. } \\
\text { - Development planning: } \\
\text { labour, impacts analysis }\end{array}$ \\
\hline Access & $\begin{array}{l}\text { Economically, } \\
\text { Socially }\end{array}$ & $\begin{array}{l}\text { - Land use planning: } \\
\text { distribution, } \\
\text { transportation } \\
\text { - Development planning: } \\
\text { income, social and } \\
\text { culture }\end{array}$ \\
\hline Utilization & $\begin{array}{l}\text { Economically, } \\
\text { Socially, }\end{array}$ & $\begin{array}{l}\text { Development planning: } \\
\text { technology, added } \\
\text { value, social and } \\
\text { culture in food } \\
\text { consumption }\end{array}$ \\
\hline
\end{tabular}

Although it has been sought that the profile of food security must be linked to sustainable agriculture development by land use planning, in general the relations between land use planning and food security are still poorly understood and implemented, inadequately articulated, and not readily apparent to most people [1]. It still let too many persons who operate in the separate fields. Food security and agriculture development with the specific links to land use planning have to be recognized by any stakeholders and legislative or policy mechanism too. This paper reveals that food security can't simply be solved by land use planning for agriculture itself, but also need a policy in terms of integration agriculture and non-agriculture development. Food security and agriculture development have to be prepared by multi-stakeholders within regional planning perspective [15].

For many people and organizations the link between food security and land use planning (regional planning) is still too far to happen in practice, although in broader conceptual level, there is an increasing recognition and awareness of them. Furthermore, [1] mentioned three major links between land use and food security, those are: (a) Loss of productive agricultural land which limits its productive capacity to supports food security system;(b) Framing of land use strategy and policy at the regional scale and its capacity to 
consider food production, access and consumption; (c) Location and setting of land uses which relate to food production, access to food and the consumption of food. At the local level, it seems that the land use planning can directly impact on the growing of food and access to food.

In its implementation, so far there are some problems have been indicated in Indonesia, as well as in West Sumatra Province, among others:

1. The difficulties in growing consistency of regional planning in either horizontal or vertical hierarchies, because food security program is not clearly registered in land use plan. Then, it is hard to achieve accountability for implementing the program;

2. Developing functional regions have been chosen as an approach for agriculture development to attain food security, but have been being implemented in territorial approach and thought. In some extents, it is lack of coordination and communications among the local or district leaders, as in [16];

3. Short of consistency among long-term, mid-term, and short-term development plan related to food security and agriculture development. Indonesian government declared that state, provinces, and districts have to protect some amount of land as sustainable agricultural land for food. It should be supported by land use plan which considered multidimensional roles and aspects from national to local level.

Consequently, though Indonesia has very rich natural resources to produce agricultural products, it still imported the amount of $12,878,878$ ton of food in year 2012 [17]. To solve those problems, some recommendations as follows:

1. Changing paradigms of leaders, planner and politician from single-sector to multidisciplinary planning thought (regional planning);

2. Increasing people control in democratic ways to ensure that land has been being used as its function which is documented in land use plan;

3. Doing joint research on suitable and sustainable land for food crops, which done by multi-stakeholders, at national, provincial or district level. Some field research areas can be in the area of food diversification and land suitability, agriculture zone mapping, agroclimate and agricultural land availability, ecosystem, social culture and local wisdom in land marketing, and sustainable agricultural land regulation, etc.

\section{CONCLUSIONS}

Food security is urgently a vital human basic need that requires the regional planning but has not yet been implemented intensely. Bridging food security and sustainable agriculture development by using regional planning will lead to multidimensional roles and impacts on food security in terms of availability, access, and utilization.
Food security that aims at an active and healthy life of people should be designed as multi-sector incorporation and multidisciplinary thoughts, which then relates to sustainable agriculture development by using the regional planning approach.

\section{ACKNOWLEDGMENT}

I would like to thank the Rector of Andalas University for the financial support so that the ideas of this paper.

\section{REFERENCES}

[1] The Victorian Local Governance Association (VLGA), Integrating Land Use Planning and Community Food Security: A New Agenda for Government to Deliver on Sustainability, Economic Growth, and Social Justice., La Trobe University, Bendigo Campus, 2009.

[2] Metro news, Meroketnya Harga Daging Sapi (Increased Price of Meat). Bincang Pagi, 16 August 2015 at. 06.45 am. Jakarta. 2015.

[3] Food and Agriculture Organization of the United Nations, Building a Common Vision for Sustainable Food and Agriculture: Principles and Approaches. E-ISBN 978-92-5-108472-4 (pdf). Rome. 2014.

[4] The Republic of Indonesia, Undang-Undang RI No. 18 Tahun 2012 Tentang Pangan. Jakarta, 2012.

[5] Department of Agriculture, the Republic of Indonesia, Statistik Konsumsi Pangan. Centre for Data and Information. The Ministry of Agriculture. Jakarta, 2012.

[6] The Republic of Indonesia, Undang-Undang RI No. 18 Tahun 2012 Tentang Pangan. Jakarta, 2012.

[7] The Republic of Indonesia, Peraturan Pemerintah No. 86 tahun 2002 tentang Ketahanan Pangan., Jakarta, 2002.

[8] Department of Agriculture, the Republic of South Africa Policy on Agriculture in Sustainable Development. Pretoria, 2002.

[9] Manelli, Alberto, New Paradigms for a Sustainable Well-Being, Agriculture and Agricultural Science Procedia 8. P 617-627. Elsevier. 2016.

[10] Fabbrizzi, Sara et all, Sustainability and Food: A Text Analysis of the Scientific Literature, Agriculture and Agricultural Science Procedia 8. P 670-679. Elsevier. 2016.

[11] Department of Agriculture, The Republic of Indonesia, Peraturan Menteri Pertanian No.50/ Permentan/CT.140/8/2012 tentang Pedoman Pengembangan Kawasan Pertanian., Jakarta, 2012.

[12] Nurliani, and Ida Rosada, Rice-Field Conversion and Its Impact on Food Availability. Agriculture and Agricultural Science Procedia 9. P 40-46. Elsevier. 2016.

[13] The Republic of Indonesia, Undang-Undang RI No. 41 Tentang Lahan Pertanian Pangan Berkelanjutan. Jakarta. 2009.

[14] Mittal, Surabhi and Deepti Sethi, Food Security in South Asia: Issues and Opportunities. Indian Council for Research on International Economic Relations (ICRIER). India Habitat Center. New Delhi. 2009

[15] Noer, Melinda, Agropolitan dan Kawasan Ketahanan Pangan: Kasus Studi Agropolitan Mungka di Kabupaten Lima Puluh Kota Propinsi Sumatera Barat., Paper presented in National Seminar on Food Security, held by University of Jambi, February 2011.

[16] Carthy and Zen, Inside Indonesia. Collaboration paper by Australian National University and University of North Sumatra. Inside Indonesia No. 114, Oct-Dec 2013 edition. 2013.

[17] The Ministry of Agriculture, the Republic of Indonesia. Kebijakan Pembangunan Pertanian 2015-2019, Jakarta, 2014. 